\title{
PENGEMBANGAN SISTEM DATABASE ONLINE MONITORING (OnLimo) KUALITAS AIR
}

\author{
Oleh : \\ Heru Dwi Wahjono \\ Pusat Pengkajian dan Penerapan Teknologi Lingkungan, BPPT
}

\begin{abstract}
Recent water quality decrease has caused difficult in finding clean water source for people and their daily life. Monitoring on water quality had been carried out many times, from up stream to down stream. It's necessary to do Online Monitoring on ground and underground water quality continuously, so that the effect of water quality decrease could be detected earlier and handle directly. The output of water quality data needs to be processed so that the society and the decision makers could see the information publicly. So, we need a design of structured database of online and real-time water quality data processing. Water quality data management using structured data base system could make water source data retracing easier.
\end{abstract}

Katakunci : database struktur, online monitoring, real time monitoring

\section{PENDAHULUAN}

\subsection{Latar Belakang}

Penurunan kualitas air merupakan salah satu bentuk penurunan kualitas lingkungan sebagai akibat dari tingkat pertambahan penduduk yang semakin tinggi dan peningkatan jumlah industri di Indonesia. Penurunan kualitas air yang terjadi saat ini mengakibatkan sulitnya mendapatkan sumber air bersih yang dapat dikonsumsi oleh masyarakat baik untuk keperluan hidup seharihari maupun untuk keperluan industri. Sebagian daerah di tanah air malah mengalami kehilangan sumber air bersih bahkan beberapa daerah ada yang mengalami kekeringan. Krisis air yang terjadi saat ini tidak lain adalah akibat dari perusakan lingkungan perairan baik oleh industri ataupun oleh masyarakat itu sendiri.

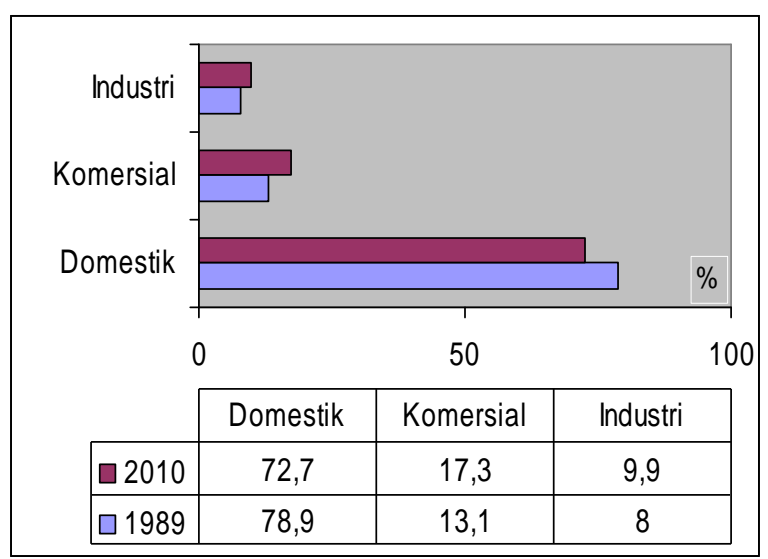

Gambar 1: Grafik Prosentase Sumber Penghasil Limbah Cair ke Sungai-sungai di Jakarta

Sumber : JICA Report, "The Study On Urban Drainage and Waste Water Disposal Project In The City Of Jakarta“, 1990
Studi pengamatan limbah cair yang telah dilakukan oleh JICA pada tahun 1990 memberikan kesimpulan bahwa limbah cair domestik lebih banyak mencemari sungai-sungai yang ada di Jakarta. Gambar grafik di atas menunjukkan prosentase perbandingan air limbah yang dibuang di sungai-sungai di Jakarta. Pada tahun 1989 kontribusi limbah cair domestik sebanyak $78,9 \%$ sedangkan limbah cair industri hanya $8 \%$. Pada tahun 2010 perkiraan kontribusi limbah cair domestik adalah menurun $72.7 \%$ sedangkan limbah cair industri meningkat menjadi 9,9\% (1).

Dalam rapat antar Menteri Dalam Negeri, Menteri Kehutanan, dan Menteri Pekerjaan Umum pada tahun 1984 mengenai penangan-an konservasi air tanah dalam rangka pengamanan Daerah Aliran Sungai (DAS) prioritas telah menyatakan sejumlah 22 DAS sebagai super prioritas, artinya mendapatkan prioritas utama dalam pembangunan dan peningkatan kualitas air di dalamnya. Sejak itu penanganan DAS kritis yang seharusnya dapat mengurangi jumlah DAS kritis, ternyata menghasilkan hal sebaliknya, yaitu peningkatan jumlah DAS yang kritis seperti terlihat pada tabel di bawah ini. (2)

Tabel 1. Jumlah DAS Kritis 1984 2003

\begin{tabular}{|c|c|}
\hline Tahun & Jumlah DAS Kritis \\
\hline 1984 & 22 \\
\hline 1994 & 39 \\
\hline 1998 & 42 \\
\hline 2000 & 58 \\
\hline 2003 & 62 \\
\hline
\end{tabular}


Kegiatan pemantuan kualitas air telah banyak dilakukan oleh berbagai instansi secara rutin, namun hasilnya tidak dipublikasikan, sehingga tidak banyak masyarakat yang tahu mengenai kualitas air di wilayah sekitarnya. Masyarakat akan tahu setelah terjadi bencana atas kerusakan kualitas air tersebut terhadap kehidupan mereka. Pemantauan kualitas air secara manual yang telah dilakukan periodik tersebut banyak mengalami hambatan terutama masalah biaya yang besar dan waktu yang lama untuk melakukan pemantauan suatu daerah di salah satu DAS kritis.

Dari uraian beberapa masalah di atas, maka dipandang perlu untuk melakukan pemantuan kualitas air secara real time dan online, sehingga datanya dapat dilihat kapan saja dan dari mana saja baik oleh masyarakat umum, LSM lingkungan, industri maupun pejabat pemerintah pengambil keputusan di pusat atau di daerah. Untuk menunjang kegiatan online monitoring ini perlu dikembangkan sebuah sistem pengelolaan basis data terstruktur dan sistem informasi untuk penyebaran informasinya.

\subsection{Permasalahan}

Model pemantuan kualitas air yang telah dilakukan secara rutin selama ini oleh beberapa instansi terkait membutuhkan biaya yang tidak sedikit dan waktu yang lama, karena dilakukan melalui beberapa tahapan kegiatan secara manual, yaitu :

- Survei pengambilan sampling air

- Menguji sampling air di laboratorium

- Menganalisa hasil pengujian laboratorium

- Membukukan hasil pengujian

- Mempublikasikan hasil pengujian

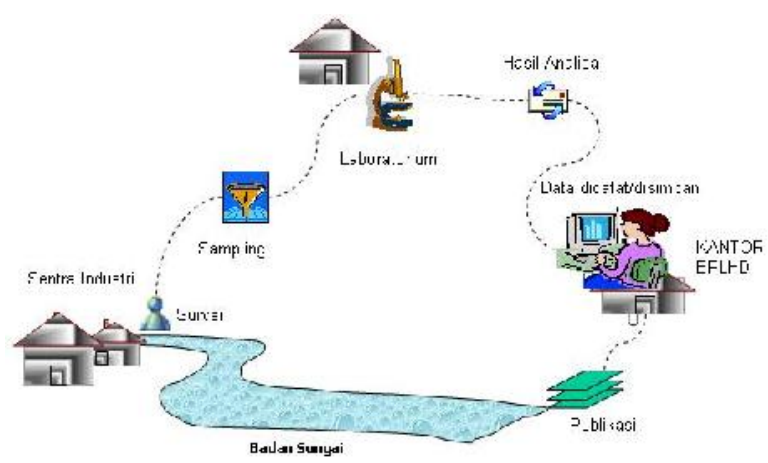

Gambar 2 : Model Pemantauan Kualitas Air Saat Ini

Model pemantauan seperti di atas memiliki beberapa kendala permasalahan, antara lain :

1. Membutuhkan biaya yang banyak jika dilakukan untuk beberapa lokasi pemantauan.

2. Tersedia biaya jika ada anggaran tahunan.
3. Proses pemantuan membutuhkan waktu yang lama.

4. Data terbaru tidak dapat diperoleh dengan cepat tergantung pada anggaran proyek.

5. Contoh air bisa dimanipulasi, misalnya dengan pengenceran.

6. Keakuratan hasil analisa laboratorium dapat terjamin, namun bisa dimanipulasi.

7. Hasil analisa hanya berupa dokumen cetak.

8. Komputerisasi hanya digunakan untuk membuat dokumentasi laporan/publikasi data analisa laboratorium.

9. Tidak tersedia katalog data atau sistem penelusuran data secara manual.

10. Publikasi data dalam bentuk cetak terbatas.

\subsection{Tujuan dan Sasaran}

Tujuan kegiatan ini adalah melakukan perancangan sistem basis data terstruktur untuk monitoring kualitas air secara online dan real time. Adapun sasarannya adalah :

1. Diperoleh disain teknis database online monitoring kualitas air.

2. Diperoleh disain user interface software online monitoring kualitas air.

\subsection{Manfaat yang Diharapkan}

Manfaat yang diharapkan dari kegiatan perancangan sistem data base untuk online monitoring kualitas air ini adalah:

1. Memberi masukan tentang perlunya dilakukan monitoring kualitas air secara online dan real time.

2. Tersedianya suatu rancangan sistem data base online yang dapat digunakan untuk pengembangan sistem informasi kualitas air.

3. Tersedianya model pemantauan kualitas air real time sebagai alternatif untuk peningkatan sistem monitoring di beberapa instansi terkait.

4. Dengan terbangunnya sistem ini diharapkan informasi kualitas air dapat diakses secara langsung dari sumbernya (pusat data dan stasiun pemantauan) secara terbuka.

\subsection{Lingkup Kegiatan}

Kegiatan pengembangan perangkat lunak sistem database untuk online monitoring (OnLimo) kualitas air merupakan bagian dari kegiatan pengembangan perangkat keras sistem monitoring kualitas air menggunakan unit data logger yang mampu mengirimkan datanya melalui SMS (Short Message Service) dengan memanfaatkan teknologi jaringan GSM (Global System for Mobile Communication). Adapun lingkup kegiatan pengembangan sistem perangkat lunak database online monitoring untuk kualitas airnya adalah sebagai berikut : 
1. Identifikasi masalah kebijakan nasional dan daerah mengenai pengendalian pencemaran air.

2. Identifikasi data kualitas air dan pengumpulan serta inventarisasi data di lapangan.

3. Perancangan sistem database dan bentuk tampilan yang akan dipakai dalam menyusun struktur data.

4. Pengembangan perangkat lunak basis data online monitoring kualitas air.

\section{KEBIJAKAN PEMERINTAH MENGENAI PENGENDALIAN PENCEMARAN AIR}

Pemerintah baik pusat maupun daerah telah mengupayakan peningkatan kualitas air melalui beberapa kegiatan, salah satunya adalah dengan mengeluarkan beberapa peraturan perundangan yang dapat dijadikan pedoman bagi masyarakat baik itu perorangan maupun industri dalam hal pengendalian pencemaran air. Beberapa peraturan perundangan yang telah disyahkan antara lain:

1. Peraturan Pemerintah R.I. Nomor 20 Tahun 1990, Tanggal 5 Juni 1990 Tentang Pengendalian Pencemaran Air. Peraturan ini mengatur kualitas air berdasarkan golongan A, B, C, dan D sesuai peruntukan sumber air.

2. Peraturan Pemerintah R.I. Nomor 82 Tahun 2001, Tanggal 14 Desember 2001 Tentang Pengelolaan Kualitas Air dan Pengendalian Pencemaran Air. Peraturan ini mengatur kaulitas air berdasarkan kelas I, II, III, dan IV sesuai peruntukan sumber air.

3. Keputusan Menteri Kesehatan R.I. Nomor 907/MENKES/SK/VII/2002, Tanggal 29 Juli 2002 Tentang Syarat-Syarat dan Pengawasan Kualitas Air Minum. Keputusan menteri ini mengatur baku mutu kualitas air yang diperuntukan sebagai air minum.

4. Keputusan Menteri Lingkungan Hidup Nomor KEP-51/MENLH/10/1995, Tanggal 23 Oktober 1995 Tentang Baku Mutu Limbah Cair Bagi Kegiatan Industri. Keputusan menteri ini mengatur baku mutu kualitas air limbah yang dibuang industri. Ada 21 industri yang diatur secara khusus baku mutu air imbahnya.

5. Keputusan Menteri Lingkungan Hidup Nomor KEP-52/MENLH/10/1995, Tanggal 23 Oktober 1995 Tentang Baku Mutu Limbah Cair Bagi Kegiatan Hotel. Keputusan menteri ini mengatur baku mutu kualitas air limbah yang dibuang oleh kegiatan perhotelan.

6. Keputusan Menteri Lingkungan Hidup Nomor KEP-58/MENLH/12/1995 Tentang Baku Mutu Limbah Cair Bagi Kegiatan Rumah Sakit. Keputusan menteri ini mengatur baku mutu kualitas air limbah yang dibuang oleh kegiatan rumah sakit dan puskesmas.
Di dalam PP No. 82 Tahun 2001 tentang pengelolaan kualitas air dan pengendalian pencemaran air telah didefinisikan beberapa batasan istilah untuk kegiatan pemantauan kualitas air, antara lain : (3)

- Air adalah semua air yang terdapat di atas dan di bawah permukaan tanah kecuali air laut dan air fosil.

- Sumber air adalah wadah air yang terdapat di atas dan di bawah permukaan tanah, termasuk dalam pengertian ini akuifer, mata air, Sungai, rawa, danau, situ, waduk, dan muara.

- Mutu air adalah kondisi kualitas air yang diukur dan atau diuji berdasarkan parameterparameter tertentu dan metoda tertentu berdasarkan peraturan perundang-undangan yang berlaku.

- Baku mutu air adalah ukuran batas atau kadar makhluk hidup, zat, energi, atau komponen yang ada atau harus ada dan atau unsur pencemar yang ditenggang keberadaannya di dalam air.

- Status mutu air adalah tingkat kondisi mutu air yang menunjukkanl kondisi cemar atau kondisi baik pada suatu sumber air dalam waktu tertentu dengan membandingkan dengan baku mutu air yang ditetapkan.

- Air limbah adalah sisa dari suatu usaha dan atau kegiatan yang berwujud cair.

- Baku mutu air limbah adalah ukuran batas atau kadar unsur pencemar dan atau jumlah unsur pencemar yang ditenggang keberadaanya dalam air limbah yang akan dibuang atau dilepas ke dalam sumber air dari suatu usaha dan atau kegiatan.

Di dalam PP No. 82 Tahun 2001 juga diatur tentang pembagian wewenang pengelolaan dan pengendalian pencemaran air antara pemerintah pusat, pemerintah provinsi dan pemerintah kota / kabupaten seperti pada tabel berikut di bawah ini: (3)

Tabel 2. Pembagian Wewenang Pengelolaan dan Pengendalian Pencemaran Air oleh Pemerintah

\begin{tabular}{|l|l|}
\hline Pemerintah & \multicolumn{1}{|c|}{ Wewenang } \\
\hline Pusat & $\begin{array}{l}\text { Melakukan pengelolaan kualitas air } \\
\text { dan pengendalian air lintas provinsi } \\
\text { dan atau lintas batas negara }\end{array}$ \\
\hline Provinsi & $\begin{array}{l}\text { Mengkoordinasikan pengelolaan } \\
\text { kualitas air dan pengendalian } \\
\text { pencemaran air lintas kabupaten/kota }\end{array}$ \\
\hline Kabupaten/Kota & $\begin{array}{l}\text { Melakukan pengelolaan kualitas air } \\
\text { dan pengendalian pencemaran air di } \\
\text { kabupaten/kota }\end{array}$ \\
\hline
\end{tabular}




\section{TINJAUAN PUSTAKA}

\subsection{Sistem Telemetri Monitoring}

Model pemantuan kualitas air telemetri (tele: jarak jauh, metri: pengukuran) yang ada saat ini berdasarkan metode pengukurannya terdiri dari tiga macam, yaitu : (4)

1. Time Base Telemetri (Pengiriman data digerakkan oleh waktu) ${ }^{(4)}$

Pada metode time base, pengukuran kualitas air dilakukan berdasarkan setting waktu yang telah ditentukan. Peralatan data logger akan diaktifkan oleh sistem waktu yang ada di stasiun monitoring untuk melakukan pengukuran dan mengirimkan hasilnya ke pusat data. Sistem seperti ini banyak digunakan pada masa awal dikembangkannya telemetri.

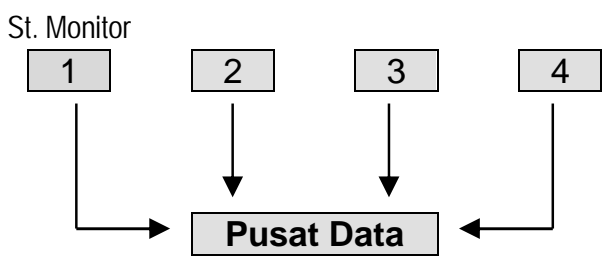

Gambar 3. Model Time Base Telemetri

2. Polling base Telemetri (Pengiriman data digerakkan oleh perintah dari pusat data) ${ }^{(4)}$

Jika terdapat banyak stasiun monitoring, setting waktu pengukuran di setiap stasiun menjadi sulit. Pada metode polling ini setting jadwal waktu pengukuran kualitas air dapat dilakukan berdasarkan perintah yang diberikan oleh pusat data. Sistem ini merupakan pengembangan terhadap sistem telemetri sebelumnya.

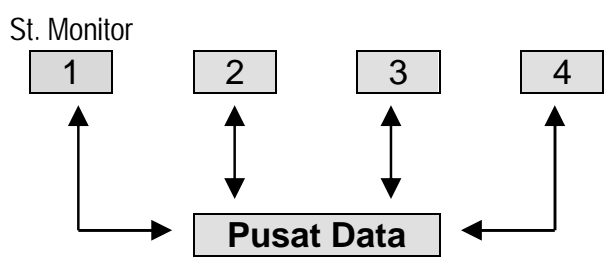

Gambar 4. Model Polling Telemetri

3. Event Base Telemetri (Pengiriman data digerakan oleh adanya peristiwa atau perubahan parameter) (4)

Dengan perkembangan teknologi digital, pengukuran data dapat dilakukan dengan tingkat ketelitian tinggi, dan berkat kemajuan teknologi komunikasi data dan mikro elektronika saat ini, pengiriman data dapat dilakukan dengan biaya murah dan sangat cepat, yaitu kurang dari $1 / 4$ detik. Sehingga data logger dapat segera mengirimkan data ke pusat data jika terdapat pencemaran air atau kejadian dimana hasil pengukuran telah melebihi baku mutu. Hal inilah yang menjadi prinsip kerja event base telemetri.

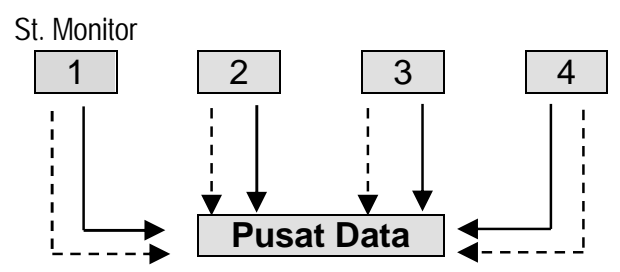

Gambar 5. Model Event Base Telemetri

\subsection{Teknologi Telekomunikasi Data}

Ada beberapa teknologi jaringan komunikasi yang dapat digunakan sebagai media transmisi data, yaitu :

1. Jaringan Telepon Kabel (TELKOM)

2. Radio (Gelombang FM)

3. Satellite Immarsat / AMPS (Autonomously Managed Power System)

4. GSM (Global System Mobile Communication)

5. CDMA (Code Division Multiple Access)

Kelima teknologi di atas memiliki keunggulan dan kelemahan yang berbeda-beda baik ditinjau dari sisi kualitas teknologi maupun dari sisi ekonomis pengadaan peralatan.

Teknologi telekomunikasi mobile GSM dan CDMA yang merupakan teknologi generasi ke 3 (3G) saat ini paling banyak digunakan, yaitu sekitar 120 juta pengguna di seluruh dunia dan di kurang lebih 120 negara. ${ }^{(5)}$ Selain biayanya murah, bermacam-macam fasilitas dapat diberikan oleh teknologi ini, di antaranya adalah akses jaringan global internet dan layanan SMS (Short Message Service). Selain banyaknya operator penyedia jasa telekomunikasi GSM dan CDMA yang memberikan berbagai peringkat pilihan harga, juga cakupan wilayahnya dapat mencapai ke seluruh pelosok di daerah terpencil sekali pun.

Perangkat telepon genggam (hand phone) yang ada di pasaran dapat digunakan sebagai alat pengirim data menggunakan multi mode frekwensi yang disediakan oleh operator telekomunikasi. Untuk jaringan GSM disediakan mode frekwensi dari $900 \mathrm{MHz}, 1.800 \mathrm{MHz}$ sampai $1.900 \mathrm{MHz}$. Untuk jaringan CDMA disediakan mode frekwensi $800 \mathrm{MHz}$ dan $1.900 \mathrm{MHz}$. Sedangkan jaringan AMPS menggunakan frekwensi $800 \mathrm{MHz}$. ${ }^{(6)}$ 
Layanan SMS yang disediakan umumnya memiliki kapasitas 140 byte data, yaitu 160 karakter untuk 7-bit, atau 140 karakter untuk 8-bit atau 70 karakter untuk 2-byte karakter china dalam sekali pengiriman dengan biaya pengiriman berkisar antara Rp. 150 sampai Rp. 350. (7) Jumlah 160 karakter ini cukup untuk mengirimkan informasi pengukuran kualitas air yang berisi data-data :

1. Nomor stasiun monitoring

2. Tanggal pengukuran

3. Jam pengukuran

4. Hasil pengukuran parameter ukur (bisa lebih dari satu parameter ukur)

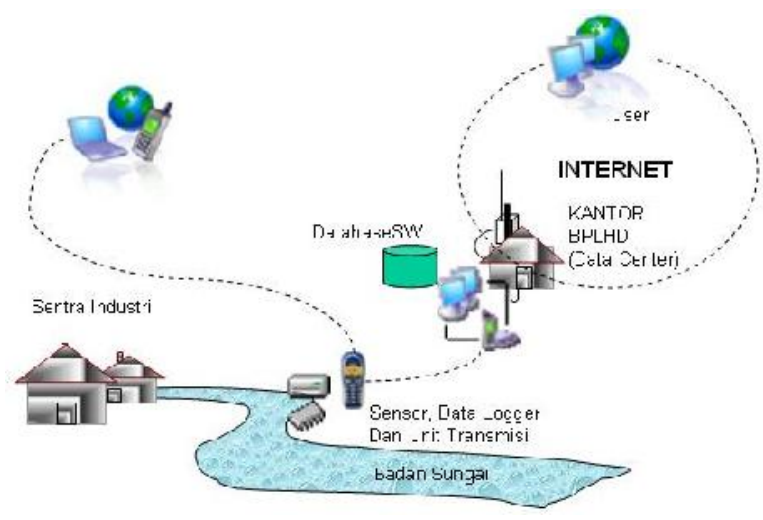

Gambar 6. Model Pemantauan Kualitas Air Online

\subsection{Konsep Pengembangan Sistem}

Di dalam ilmu informatika dan komputer, pengembangan sebuah perangkat lunak, secara konseptual memiliki suatu evolusi (Software Evolutaion), yang terdiri dari rangkaian aktivitas yang akan terjadi selama proses pengembangan dan pemeliharaan sistem software tersebut. (8) Aktifitas tersebut antara lain :

- System Initiation/Adoption

- Requirement Analysis and Specification

- Functional Specification or Prototyping

- Partition and Selection (Build/Buy/Reuse)

- Architectural Configuration Specification

- Detailed Component Design Specification

- Component Implementation and Debugging

- Software Integration and Testing

- Documentation and System Delivery

- Training and Use

- Software Maintenance

Di dalam software evolution yang terdiri serangkain aktivitas di atas menyajikan berbagai macam metodologi berupa model daur hidup perangkat lunak (Software Life Cycle) (9), yaitu :

1. Model Build and Fix

2. Model Prototyping

3. Model Incremental

4. Model Spiral

\section{Model Waterfall / SDLC (Software Development Live Cycle)}

Pengembangan sistem software umumnya menggunakan metodologi System Development Live Cycle (SLDC) yang artinya siklus hidup pengembangan sistem. Dari kelima model metodologi di atas, model waterfall adalah model pengembangan sistem yang paling banyak digunakan (9). Model ini memiliki tahapan :

1. Scope and Objective

2. Feasibility Study

3. System Analysis

4. System Design

5. Detailed Design

6. Implementation

7. Changeover

8. Evaluation \& Maintenance

\section{PELAKSANAAN KEGIATAN}

\subsection{Peralatan Online Monitoring}

Kegiatan pengembangan database online monitoring kualitas air sangat bergantung pada kegiatan pengembangan perangkat kerasnya. Komponen monitoring ini terdiri dari beberapa sub sistem, yaitu :

- Unit sensor dan data logger (OnLimo-DL)

- Unit komunikasi/transmisi data (OnLimo-DT)

- Unit pengolah data / data center (OnLimo-DC)

- Sistem software database (OnLimo-SW)

Lokasi penempatan unit data logger dan sensor dapat diletakkan di beberapa obyek lokasi pengukuran selama masih berada di bawah cakupan wilayah layanan jaringan GSM, yaitu :

- Badan Sungai

- Muara Sungai

- Sepanjang Pantai

- Tengah Lautan

Ada beberapa parameter ukur yang dapat digunakan untuk analisa kualitas air yang telah diatur oleh peraturan perundangan. Namun tidak semua parameter dapat digunakan untuk sistem online monitoring secara langsung karena sangat tergantung dari kemampuan sensor digital yang ada di pasaran. Sensor digital yang dapat dipakai untuk online monitoring adalah sensor digital untuk parameter kualitas air yang bersifat electrochemical, yaitu ${ }^{(10)}$ :

Tabel 2. Parameter Ukur Untuk Online Monitoring

\begin{tabular}{|l|c|c|c|}
\hline \multicolumn{1}{|c|}{ Parameter } & $\begin{array}{c}\text { Baku } \\
\text { Mutu }\end{array}$ & Satuan & $\begin{array}{c}\text { Metode } \\
\text { Pengukuran }\end{array}$ \\
\hline $\begin{array}{l}\text { Dissolved } \\
\text { Oxygen }\end{array}$ & $0-20$ & $\mathrm{mg} / \mathrm{l}$ & Voltameter \\
\hline
\end{tabular}




\begin{tabular}{|l|c|c|l|}
\hline Turbidity & $0-500$ & NTU & Light extinction \\
\hline Conductivity & $0-2000$ & $\mu \mathrm{S} / \mathrm{cm}$ & $\begin{array}{l}\text { Conductivity } \\
\text { meter }\end{array}$ \\
\hline Temperatur & $0-50$ & $\mathrm{C}^{\circ}$ & Digital \\
\hline $\mathrm{pH}$ & $0-14$ & $\mathrm{mg} / \mathrm{l}$ & Potentiometer \\
\hline Ammonium ion & $0-10$ & Phometry \\
\hline TOC & $0-20$ & $\mathrm{mg} / \mathrm{l}$ & $\begin{array}{l}\text { UV induced } \\
\text { oxidation }\end{array}$ \\
\hline Floating oil & - & - & $\begin{array}{l}\text { Surface sample } \\
\text { for TOC } \\
\text { measurement }\end{array}$ \\
\hline Chlorofyll-a & $0,1<$ & $\mu \mathrm{g} / \mathrm{l}$ & Fluorometria \\
\hline $\begin{array}{l}\text { Biomonitor } \\
\text { (toxicity meter) }\end{array}$ & $0-15$ & Index T & Flourometry \\
\hline
\end{tabular}

Untuk monitoring kualitas air yang ada di Jakarta tidak perlu memasang sensor digital untuk semua parameter di atas, karena biaya pengadaan sensor digital tersebut masih sangat mahal. Beberapa paremeter yang dapat dipakai antara lain :

1. TDS (Total Dissolved Substance) untuk mengukur jumlah zat padat terlarut.

2. DO (Dissovled Oxygen) untuk mengukur jumlah oksigen dalam air.

3. Temperatur untuk mengukur suhu larutan.

4. $\mathrm{pH}$ untuk mengukur kondisi asam/basa.

\subsection{Analisa Format Pengiriman Data}

Online monitoring kualitas air dapat dilakukan terhadap lebih dari satu lokasi pengamatan yang diwakili oleh stasiun monitoring. Untuk membedakan hasil pengukuran antara stasiun yang satu dengan stasiun yang lain perlu diberikan penomoran terhadap stasiun monitoring kualitas air. Setiap nomor stasiun merupakan nomor identitas yang bersifat unik, dimana satu nomor stasiun hanya dimiliki oleh sebuah stasiun monitoring.

Penentuan format penomoran stasiun dilakukan dengan menggunakan teknik penomoran yang telah dilakukan oleh Puslibang Air Dep. PU untuk Stasiun Pos Duga Air (PDA). Nomor stasiun terdiri dari sembilan digit angka yang terbagi ke dalam empat bagian dan dibatasi dengan tanda minus "-" sebagai berikut :

$$
\text { A - B - C - D }
$$

A : 2 digit nomor wilayah pulau

$B: 3$ digit nomor induk sungai

$C: 2$ digit nomor anak sunai

$\mathrm{D}: 2$ digit nomor urut stasiun

\begin{tabular}{|c|c|c|c|c|}
$\begin{array}{c}\text { No. } \\
\text { Pulau }\end{array}$ & $-\begin{array}{c}\text { No } \\
\text { S. Induk }\end{array}$ & $\begin{array}{c}\text { No. } \\
\text { Anak S. }\end{array}$ & $\begin{array}{c}\text { No. } \\
\text { Stasiun }\end{array}$ \\
\hline$\# \#$ & -- & $\# \# \#$ & -- & $\# \#$ \\
\hline
\end{tabular}

Dari analisa di atas, untuk merepresentasikan nomor stasiun dibutuhkan 12 karakter termasuk tanda minusnya, yang pemberian nomornya mengikuti aturan sebagai berikut :

\section{A. Nomor Pulau (\#\#)}

Nomor pulau diberikan kepada 15 pulau besar yang ada di Indonesia : (11)

Tabel 3. enomoran 15 Pulau Besar di Indonesia

\begin{tabular}{|l|l|l|l|l|l|}
\hline No & Pulau & No & Pulau & No & Pulau \\
\hline 01 & Sumatera & 06 & Madura & 11 & Sumba \\
\hline 02 & Jawa & 07 & Bali & 12 & Timor \\
\hline 03 & Kalimantan & 08 & Lombok & 13 & Seram \\
\hline 04 & Sulawesi & 09 & Sumbawa & 14 & Buru \\
\hline 05 & Irian Jaya & 10 & Flores & 15 & Halmahera \\
\hline
\end{tabular}

B. Nomor Sungai Induk (\#\#\#)

Sungai yang mengalir dan bermuara ke laut diberikan satu nomor induk sungai yang disusun mulai dari arah barat laut untuk masing-masing wilayah pulau/provinsi dan berputar mengelilingi pulau tersebut searah jarum jam. (11)

\section{Nomor Anak Sungai (\#\#)}

Setiap DAS dibagi ke dalam beberapa sub das yang lebih kecil dan di dalamnya bermuara anak sungai yang diberikan nomor untuk setiap masing-masing sub das.

D. Nomor Stasiun (\#\#)

Setiap stasiun dalam sebuah sungai induk atau sub DAS diberikan nomor urut menurut urutan tahun pembangunannya. ${ }^{(11)}$

Contoh :

Nomor stasiun monitoring Cikarang di daerah Cikarang, Jawa Barat adalah : 02-015-02-01, artinya adalah :

02 : nomor lokasi di pulau jawa

015 : nomor sungai induk Cikarang

02 : nomor anak sungai / sub DAS Cikarang

01 : stasiun monitoring pertama yang didirikan di lokasi ini

Selain data nomor stasiun diperlukan juga data tanggal, data waktu pengukuran, dan data hasil pengukuran untuk setiap parameter yang diukur. Masing-masing data mengikuti format penulisan sebagai berikut :

Tabel 4. Format Data Tanggal, Jam dan Parameter Ukur

\begin{tabular}{|l|c|c|}
\hline \multicolumn{1}{|c|}{ Data } & Format & Contoh \\
\hline Tanggal & DD / MM / YYYY & $01 / 06 / 2005$ \\
\hline Waktu & $\mathrm{HH}: \mathrm{MM}: \mathrm{SS}$ & $09: 15: 00$ \\
\hline Suhu & double & 27,83 \\
\hline DHL & double & 100,25 \\
\hline
\end{tabular}




\begin{tabular}{|l|l|c|}
\hline TDS & double & 500,65 \\
\hline Salinitas & double & 15,4 \\
\hline DO & double & 10,5 \\
\hline pH & double & 7,8 \\
\hline
\end{tabular}

Dari uraian di atas dapat ditentukan format pengiriman data untuk sekali pengiriman hasi pengukuran di setiap lokasi stasiun monitoring, yaitu :

Format :

\begin{tabular}{l|l|l|l|l|l|l|l|l|} 
STAT & TGL & JAM & SUHU & DHL & TDS & SAL & DO & pH
\end{tabular}

Jumlah karakter (Total 63 Karakter) :

12

10

8

5

7

\begin{tabular}{l|l|l|l}
7 & 5 & 5 & 4
\end{tabular}

\subsection{Disain Database OnLimo}

Ada tiga entitas data yang perlu dikelola dalam online monitoring kualitas air, yaitu :

1. Entitas Stasiun

Entitas ini berisi informasi umum mengenai stasiun monitoring kualitas air. Atribut informasinya antara lain :

- Nomor Stasiun

- Nama Stasiun

- Alamat Stasiun

- Nomor HP unit data logger

- Koordinat Lintang Lokasi

- Koordinat Bujur Lokasi

- Kontak Person

- Keterangan

2. Entitas Pengukuran

Entitas ini berisi informasi mengenai tanggal dan data pengukuran. Atribut informasinya adalah :

- Tanggal Pengukuran

- Waktu Pengukuran

- Data pengukuran Suhu

- Data pengukuran DHL

- Data pengukuran TDS

- Data pengukuran Salinitas

- Data pengukuran DO

- Data pengukuran $\mathrm{pH}$

3. Entitas Pengguna

Entitas ini berisi informasi mengenai pengguna sistem online monitoring yang dapat mengakses sistem software. Atribut informasinya adalah :

- Kode login

- Nama Login

- Nama Lengkap

- Nomor telepon

- Password

- Otoritas Akses

Berdasarkan ketiga entitas di atas, maka dapat dirancang struktur database untuk pengelolaan data online monitoring kualitas air, sebagai berikut :

Tabel 5. Tabel Stasiun

\begin{tabular}{|l|l|c|}
\hline No & \multicolumn{1}{|c|}{ Nama Field } & Tipe \\
\hline 1. & IDStasiun ${ }^{*}$ & Text \\
\hline 2. & NamaStasiun & Text \\
\hline 3. & AlamatStasiun & Text \\
\hline 4. & NomorHP & Text \\
\hline 5. & KoordLintang & Double \\
\hline 6. & KoordBujur & Double \\
\hline 7. & KontakPerson & Text \\
\hline 8. & Keterangan & Memo \\
\hline
\end{tabular}

Tabel 6. Tabel Pengukuran

\begin{tabular}{|l|l|c|}
\hline No & \multicolumn{1}{|c|}{ Nama Field } & Tipe \\
\hline 1. & IDStasiun $^{*}$ & Text \\
\hline 2. & TangalPengukuran $^{*}$ & Date \\
\hline 3. & WaktuPengukuran ${ }^{*}$ & Time \\
\hline 4. & Suhu & Double \\
\hline 5. & DHL & Double \\
\hline 6. & TDS & Double \\
\hline 7. & Salinitas & Double \\
\hline 8. & DO & Double \\
\hline 9. & Suhu & Double \\
\hline 10. & pH & Double \\
\hline * primary key
\end{tabular}

Tabel 7. Tabel Pengguna

\begin{tabular}{|l|l|l|}
\hline No & \multicolumn{1}{|c|}{ Nama Field } & Tipe \\
\hline 1. & IDUser $^{*}$ & Text \\
\hline 2. & NamaUser & Text \\
\hline 3. & NamaLengkap & Text \\
\hline 4. & NoTelepon & Text \\
\hline 5. & Password & Text \\
\hline 6. & Otoritas & Text \\
\hline
\end{tabular}

Relasi tabel stasiun dan tabel pengukuran adalah seperti gambar berikut :

Tabel Stasiun

* IDStasiun

NamaStasiun

AlamatStasiun

NomorHP

KontakPerson

Keterangan
Tabel Pengukuran

\begin{tabular}{l}
\hline IDStasiun * \\
TangalPengukuran * \\
WaktuPengukuran * \\
Suhu \\
DHL \\
TDS \\
Salinitas \\
DO \\
\hline pH \\
\hline
\end{tabular}

Gambar 7. Relasi Tabel Stasiun dan Tabel Pengukuran 
Untuk keperluan manipulasi data pada sistem database online monitoring kualitas air, perlu didefinisikan juga beberapa tabel kerja (view/query) yang merupakan gabungan dari beberapa tabel inti yang memiliki relasi. Tabeltabel kerja atau query tersebut didefinisikan menggunakan bahasa query terstruktur SQL (Structured Query Language) yang merupakan bahasa standar untuk pengembangan sistem database. Beberapa tabel kerja / query yang dihasilkan antara lain :

Tabel 8 : Query Inti Database SDA

\begin{tabular}{|c|l|l|}
\hline No & \multicolumn{1}{|c|}{ Query } & \multicolumn{1}{|c|}{ Tabel } \\
\hline 1. & Data & $\begin{array}{l}\text { - Stasiun } \\
\bullet\end{array}$ \\
\hline 2. & Mengukuran \\
\hline 3. & JumlahData & $\begin{array}{l}\bullet \\
\bullet\end{array}$ \\
\hline 4. & Rengasiun \\
\hline
\end{tabular}

Data Manipulation Language (DML) untuk masing-masing query adalah sebagai berikut :

\section{Query Data :}

SELECT IDStasiun, Tanggal, Jam, Suhu, DHL, TDS, Salinitas, DO, pH FROM Stasiun INNER JOIN Pengukuran ON IDStasiun = IDStasiun ORDER BY IDStasiun, Tanggal, Jam;

\section{Query Monitoring :}

SELECT IDStasiun, NamaStasiun, AlamatStasiun, NoTelepon, KontakPerson, Keterangan, Tanggal, Jam, Suhu, DHL, TDS, Salinitas, DO, pH FROM Stasiun INNER JOIN Pengukuran ON IDStasiun = IDStasiun ORDER BY IDStasiun, Tanggal, Jam;

\section{Query JumlahData :}

SELECT IDStasiun, Tanggal, Count(Jam) AS JmlJam, NamaStasiun, Avg(Suhu) AS Rata2Suhu, Avg(DHL) AS Rata2DHL, Avg(TDS) AS Rata2TDS, Avg(Salinitas) AS Rata2Salinitas, Avg(DO) AS Rata2DO, Avg(pH) AS Rata2pH FROM Monitoring GROUP BY IDStasiun, Tanggal, NamaStasiun ORDER BY IDStasiun, NamaStasiun;

\section{Query RekapData :}

SELECT IDStasiun, NamaStasiun, Count(Tanggal) AS Jm/Tgl, Sum(JmlJam) AS JmlJam, Avg(Rata2Suhu) AS Rata2Suhu, Avg(Rata2DHL) AS Rata2DHL, Avg(Rata2TDS) AS Rata2TDS, Avg(Rata2Salinitas) AS Rata2Salinitas, Avg(Rata2DO) AS Rata2DO, Avg(Rata2pH) AS Rata2pH FROM JumlahData GROUP BY IDStasiun, NamaStasiun ORDER BY IDStasiun;
Selain keempat tabel kerja di atas, untuk menampilkan data kualitas air yang telah diukur ke dalam tampilan grafik, perlu didefinisikan DML sebagai berikut :

SELECT Jam, \&Parameter\&, \&BM1\&, \&BM2\& INTO TempTable FROM Pengukuran WHERE IDStasiun = \&IDStasiun2\& AND Tanggal = \&Tglukur\& AND Jam BETWEEN \&DariJam\& AND \&SampaiJam\& ORDER BY Jam;

Dimana arti dari masing-masing variabel pada DML di atas adalah :

\&Parameter\& : field Suhu, DHL, TDS, Sal, DO, pH \&BM1\& : batas bawah nilai baku mutu \&BM2\& : batas atas nilai baku mutu \&IDStasiun2 : nomor ID stasiun monitoring \&TglUkur\& : tanggal pengukuran \&DariJam\& : jam mulai pengukuran \&SampaiJam\& : jam akhir pengukuran

\subsection{Rancang Bangun Perngkat Lunak}

Pengembangan perangkat lunak untuk online monitoring dilakukan dengan membuat user interface pengisian data sesuai dengan tabel data dan tabel kerja yang ada. Selain itu juga disusun bentuk format laporan satuan data dan laporan rekapitulasi data pengukuran untuk menampilkan data monitoring kualitas air di setiap stasiun monitoring. Rancangan sistem pengoperasiannya seperti pada gambar berikut :

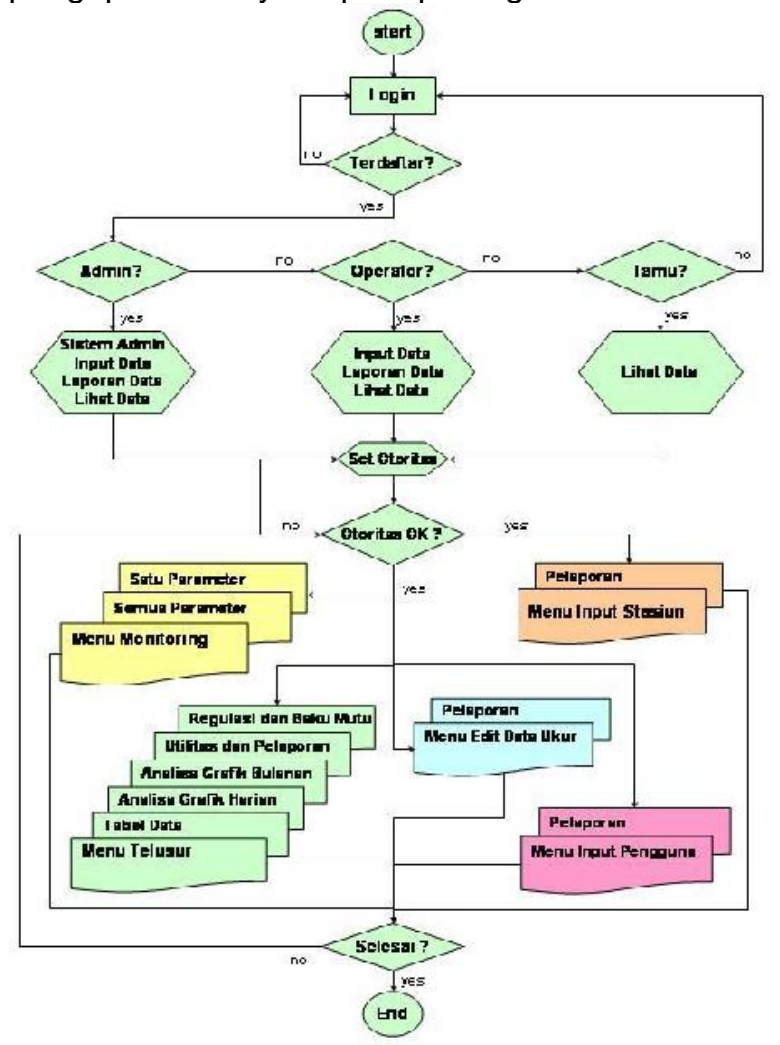

Gambar 7. Diagram Alir Proses Pengoperasian Software OnLimo 
Sistem perangkat lunak yang dikembangkan terdiri dari modul pengisian data stasiun, modul editing data pengukuran, dan modul penelusuran data, serta modul pelaporan data yang terdiri dari laporan ringkas, laporan rinci, laporan lengkap, dan laporan satuan data. Masing-masing modul telah dikembangkan sedemikian rupa sehingga dapat dengan mudah digunakan oleh pengguna sistem ini.

1. Modul Menu Utama

Modul ini akan muncul pertama kali saat pengguna berhasil login ke dalam sistem dengan otoritas aksesnya. Menu utama beris ikon untuk mengaktifkan modul-modul lain di dalamnya, yaitu :

- Ikon Monitoring

- Ikon Penelusuran

- Ikon Stasiun

- Ikon Data Ukur

- Ikon Pengguna

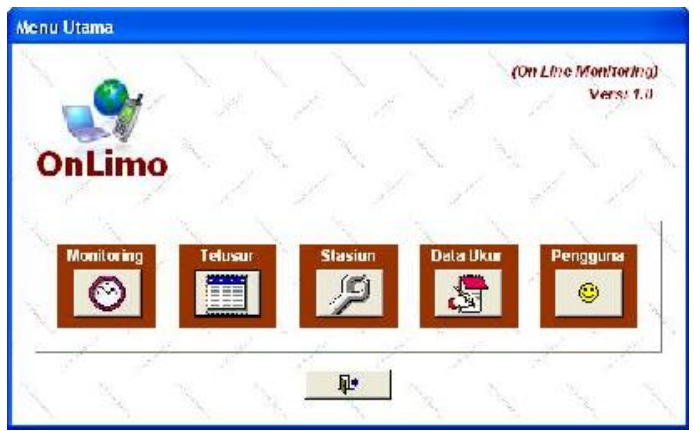

Gambar 8. Window Menu Utama

2. Modul Monitoring

Modul ini digunakan untuk memantau data yang sedang dikirim oleh data logger ke dalam sistem penerimaan data di pusat data, sehingga proses monitoring dapat dilakukan secara online dan real time. Modul ini terdiri dari dua jenis pilihan monitoring, yaitu :

- Monitoring satu parameter ukur

- Monitoring semua parameter ukur

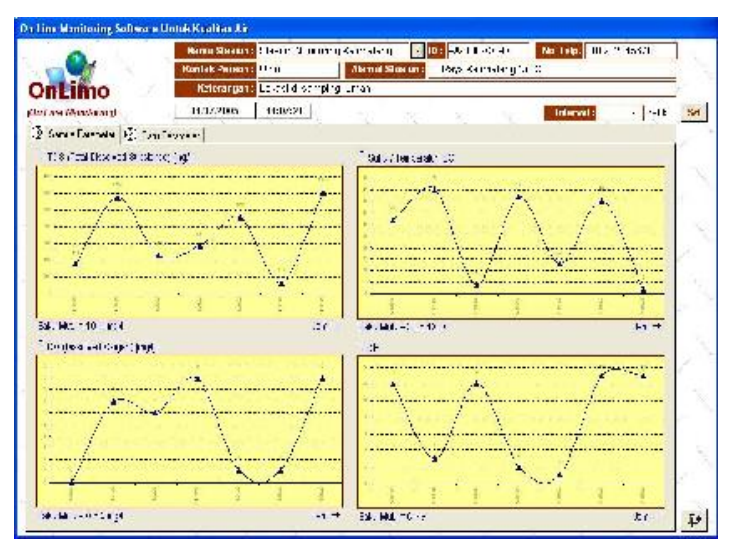

Gambar 9. Window Monitoring

\section{Modul Penelusuran}

Modul ini digunakan untuk menelusuri datadata hasil pengukuran yang telah dilakukan beberapa waktu yang lalu. Pengguna harus memasukkan tanggal, waktu, dan lokasi pengukuran serta parameter ukur yang akan ditampilkan grafiknya. Data akan ditampilkan dan dibandingkan dengan nilai baku mutu yang ada. Modul ini terdiri dari menu-menu penelusuran, yaitu :

- Tabel Data

- Analisa Grafik Harian

- Analisa Grafik Bulanan

- Utilitas dan Pelaporan

- Regulasi dan Baku Mutu

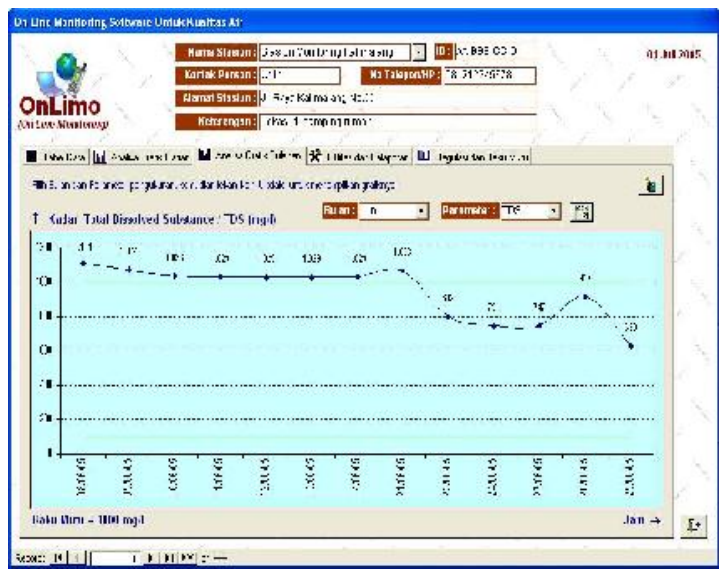

Gambar 10. Window Penelusuran Data

4. Modul Stasiun

Modul ini digunakan untuk mengedit data informasi umum mengenai lokasi stasiun monitoring yang terdiri dari dua bagian, yaitu:

- Form isian data stasiun monitoring

- Tabel data stasiun monitoring

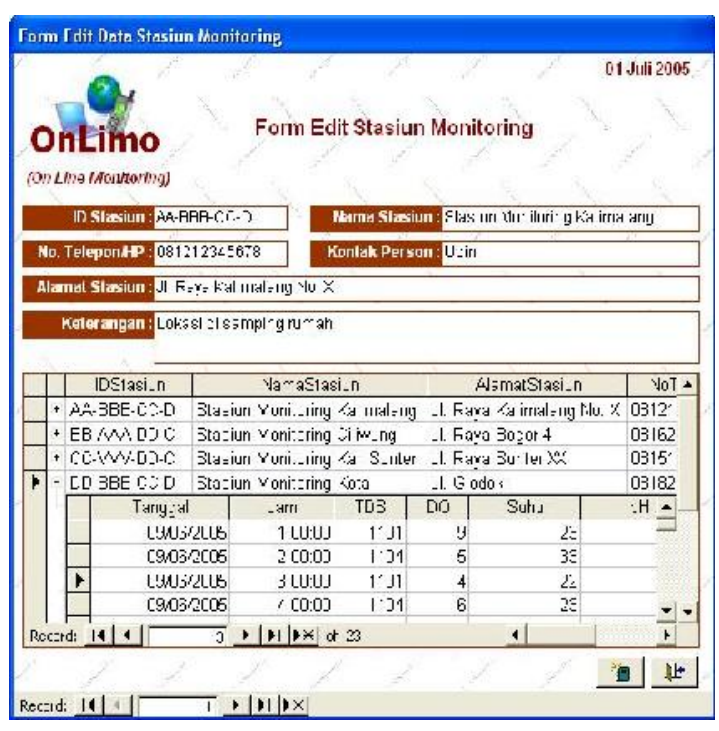

Gambar 11. Window Stasiun 
5. Modul Data Ukur

Modul ini hanya digunakan untuk mengedit data-data hasil pengukuran jika diperlukan. Data hasil pengukuran yang masuk juga akan langsung dibandingkan dengan nilai baku mutu yang ada.

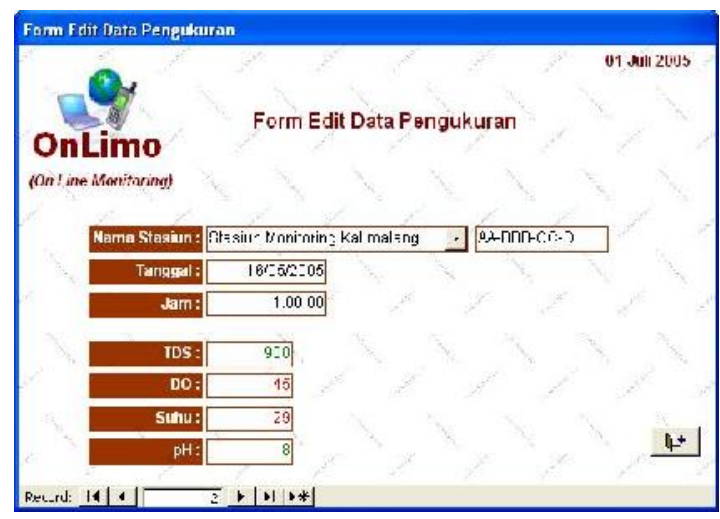

Gambar 12. Window Stasiun

6. Modul Pengguna

Modul ini digunakan untuk mengedit data pengguna sistem OnLimo, dan hanya dapat dibuka oleh pengguna dengan otoritas akses sebagai administrator. Modul ini terdiri dari dua bagian, yaitu :

- Form isian data pengguna

- Tabel data pengguna

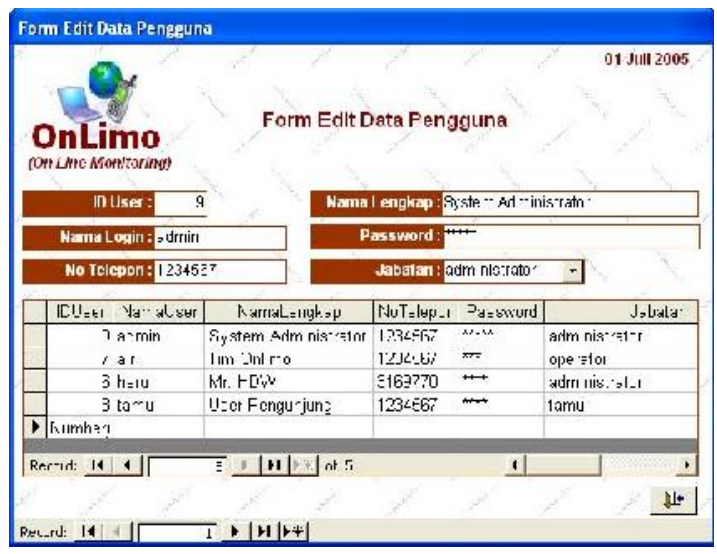

Gambar 13. Window Pengguna

\subsection{Modul Pendukung}

Untuk melengkapi kebutuhan pengguna dalam mengoperasikan sistem software nantinya perlu disiapkan modul-modul pendukung seperti :

\section{Modul Pelaporan}

Modul ini berisi rancangan berbagai bentuk dokumentasi pelaporan, antara lain : laporan ringkas, laporan rinci, laporan lengkap dan laporan satuan data.

2. Modul Regulasi dan Baku Mutu
Modul ini berisi informasi beberapa peraturan perundangan mengenai baku mutu kualitas air dan limbah cair.

3. Modul Petunjuk Pemakaian

Modul ini merupakan dokumentasi elektronik petunjuk pengoperasian sistem software secara keseluruhan.

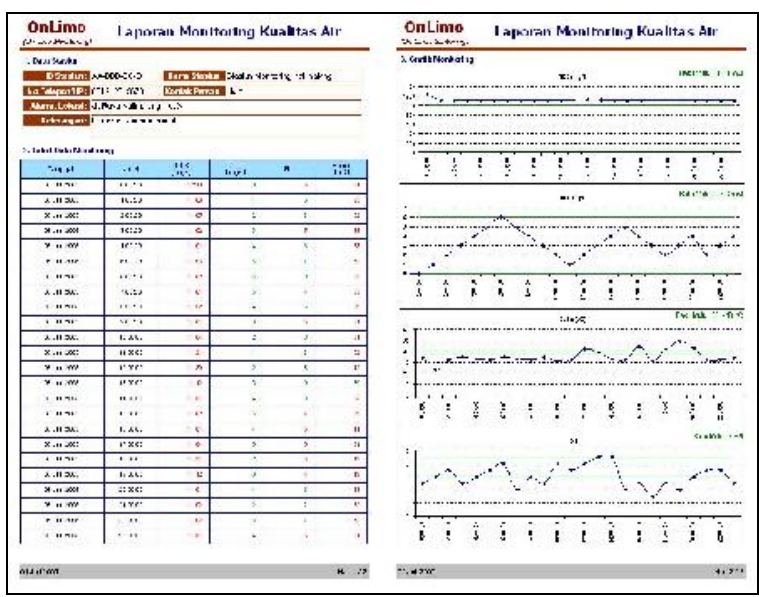

Gambar 14. Format laporan Rinci

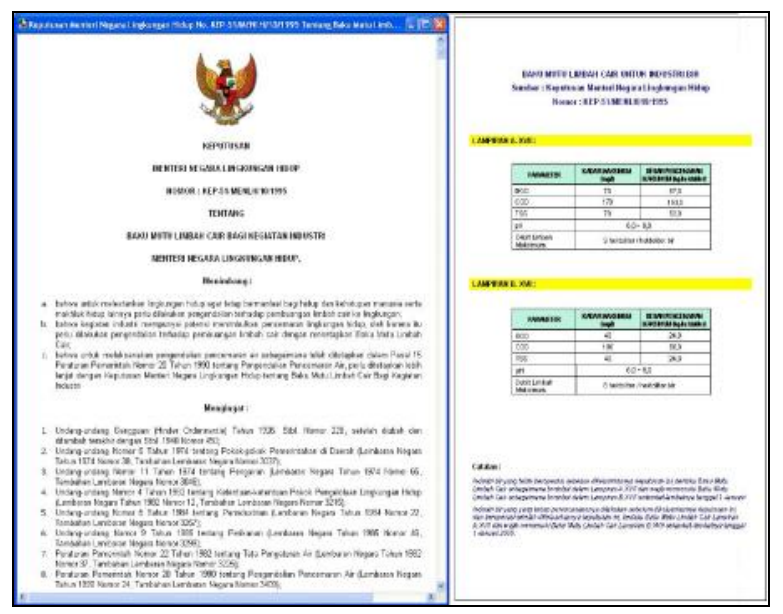

Gambar 15. Referensi Regulasi dan Baku Mutu

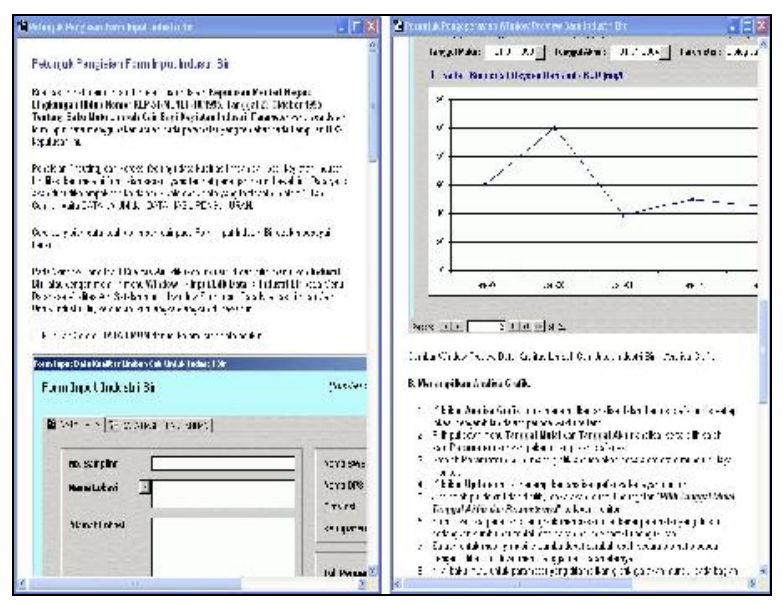

Gambar 16. Window Petunjuk Pemakaian 


\subsection{Sistem Pengamanan Data}

Untuk mengamankan data, setiap pengguna dapat diberikan otoritas akses yang berbedabeda. Otoritas ini yang membedakan akses antara pengguna yang satu dengan pengguna yang lain. Otoritas aksesnya dibagi ke dalam tiga kelompok, yaitu :

1. Administrator : memiliki semua otoritas untuk mengelola seluruh sistem.

2. Operator : memiliki otoritas memasukkan data, menelusuri dan melihat laporan data.

3. Tamu : hanya memiliki otoritas menelusuri data.

Berikut ini adalah tabel kategori pengguna dan otoritas aksesnya.

Tabel 9. Kategori Pengguna dan Otoritas Akses

\begin{tabular}{|l|c|c|c|c|}
\hline $\begin{array}{c}\text { Pengguna } \\
\text { Sistem }\end{array}$ & $\begin{array}{c}\text { Input } \\
\text { Data }\end{array}$ & $\begin{array}{c}\text { Lihat } \\
\text { Data }\end{array}$ & $\begin{array}{c}\text { Laporan } \\
\text { Data }\end{array}$ & $\begin{array}{c}\text { Sistem } \\
\text { Admin }\end{array}$ \\
\hline Administrator & $\sqrt{ }$ & $\sqrt{ }$ & $\sqrt{ }$ & $\sqrt{ }$ \\
\hline Operator & $\sqrt{ }$ & $\sqrt{ }$ & $\sqrt{ }$ & $\mathrm{X}$ \\
\hline Tamu & $\mathrm{X}$ & $\sqrt{ }$ & $\mathrm{X}$ & $\mathrm{X}$ \\
\hline
\end{tabular}

\subsection{Pengujian Perangkat Lunak OnLimo}

Untuk keperluan pengujian masing-masing modul dalam software OnLimo perlu dibuatkan data-data sementara yang dimasukkan secara manual. Khusus modul monitoring pengujiannya menggunakan data yang dihasilkan oleh secara otomatis oleh program (random.c) yang khusus dibuat menggunakan bahasa pemrograman $C$ untuk mensimulasikan data-data pengukuran tersebut.

Program random.c ini bekerja menghasilkan data dalam format yang sama dengan rancangan format data dalam software database OnLimo dan bekerja secara terpisah antara satu sama lain sehingga dapat dibuat kondisi seolah-olah random.c ini adalah unit data logger yang bertugas mengirimkan data pengukuran kualitas air di lapangan.

Contoh Data Yang Dihasilkan oleh Data Logger

AA-BBB-CC-D|01/07/2005|00:00:00|25,5|126|300|10|12|7,6

AA-BBB-CC-D|01/07/2005|01:00:00|26,0|127|289|11|11|7,7

AA-BBB-CC-D|01/07/2005|02:00:00|26,1|124|290|10|12|7,0

AA-BBB-CC-D|01/07/2005|03:00:00|26,1|125|295|12|11|8,0

AA-BBB-CC-D|01/07/2005|04:00:00|27,0|128|298|10|10|7,8

AA-BBB-CC-D|01/07/2005|05:00:00|26,1|124|290|10|12|7,0

AA-BBB-CC-D|01/07/2005|06:00:00|25,5|126|300|10|12|7,6

AA-BBB-CC-D|01/07/2005|07:00:00|27,0|128|298|10|10|7,8

AA-BBB-CC-D|01/07/2005|08:00:00|26,1|124|290|10|12|7,0

\section{KESIMPULAN}

Selama proses rancang bangun database online monitoring dapat ditarik beberapa sebagai kesimpulan antara lain :

1. Tidak semua parameter dapat dilakukan pengukuran secara online. Hanya beberapa parameter yang memiliki karakteristik electro chemical yang dapat diwakili oleh sensorsensor pemantauan.

2. Hasil pengukuran dari sensor tersebut dapat dikonversikan ke dalam beberapa parameter lain atau ke dalam unit satuan lain sesuai kebutuhan, sehingga dapat mengurangi beban kerja processor pada unit data logger.

3. Penggunaan tipe data integer untuk parameter ukur dapat lebih menghemat jumlah karakter pengiriman dan kapasitas disk jika dibandingkan dengan tipe data double.

4. Penghematan biaya pengiriman dapat dilakukan dengan memprogram data logger untuk mengirimkan data satu atau dua kali sehari.

5. Penulisan data pengukuran oleh sistem data logger dan sistem software onlimo harus memiliki format data (tanggal, jam, tanda koma dalam angka) yang sama agar data dapat diterjemahkan dengan benar ke dalam software database.

\section{DAFTAR PUSTAKA}

1. JICA (1990), The Study On Urban Drainage and Waste Water Disposal Project In The City Of Jakarta.

2. Dr. Ir. Arie Herlambang, M.Si (2005), Pencemaran Air dan Strategi Penanggulangannya

3. PP R.I. No. 82 Tahun 2001 (14/12/2001), Pengelolaan Kualitas Air dan Pengendalian Pencemaran Air

4. Syamsudin, Muharyan (1984), Sistem Telemetri

5. Hector D. Calabia (2001), Evolution 2001: CDMA versus GSM

6. Wikipedia (2005), http://en.wikipedia.org/ Multi Mode Mobile Phone

7. Wikipedia (2005), http://en.wikipedia.org/ Short Message Service, Technical Details

8. Heru Dwi Wahjono, B.Eng., M.Kom (2002), Perancangan Sistem Basis Data SDA.

9. Curtis G. (1995), Bussiness Information System $2^{\text {nd }}$ Edition. Wokingham, England: Addison Wesley

10. Hungarian Ministry for Environment and $U$. S. Agency for International Development (1996), Basic instrumentation of monitoring station (http://www.rivermonitoring.hu).

11. Balai Hidrologi (1995), Hidrology Year Book 1995 Jilid I, Direktorat Jendral Pengairan, Puslitbang Pengairan, Dep. PU. 